\title{
Indirect Free Thyroxine Measurement
}

National Cancer Institute

\section{Source}

National Cancer Institute. Indirect Free Thyroxine Measurement. NCI Thesaurus. Code C120664.

The determination of the free thyroxine present in a sample by indirect measure. 